\title{
A guerra colonial portuguesa na poesia testemunhal de Fernando Assis Pacheco e Manuel Alegre: diálogos, congruências e incongruências
}

\section{Vinícius Victor Araújo Barros* Resumo}

Este artigo debate a poesia testemunhal de Fernando Assis Pacheco e Manuel Alegre, ambos ex-combatentes da guerra colonial portuguesa em África. As análises se detêm às publicações realizadas próximas de confrontos ou ainda no calor deles, a saber: Cuidar dos Vivos (1963) e Catalabanza, Quilolo e Volta (1976), de Fernando Assis Pacheco, e Praça da Canção (1965) e Canto e as armas (1967), de Manuel Alegre. Baseados nas concepções de Walter Benjamin (2012) de crise do compromisso tácito entre o leitor e o narrador moderno e no paroxismo da impossibilidade de representação artística de uma catástrofe humana como a guerra, procuramos evidenciar como cada um dos autores portugueses elaborou esteticamente seu testemunho com o intuito de retratar em versos a brutalidade cotidiana do front e os traumas de lá trazidos. Atentos aos diálogos, às congruências e às incongruências entre as produções dos dois poetas, esperamos colocar em questão que as guerras são, paradoxalmente, experiências coletivas momentâneas, porém, individualmente vivenciadas.

Palavras-chave: Fernando Assis Pacheco. Manuel Alegre. Guerra colonial portuguesa. Testemunho. Memória.

* Universidade Federal de Goiás (UFG). Mestre em Estudos Literários e doutorando pelo Programa de Pós-graduação em Letras e Linguística da Faculdade de Letras da Universidade Federal de Goiás (PPGLL-FL-UFG). Bolsista da Coordenação de Aperfeiçoamento de Pessoal de Nível Superior (CAPES). 


\section{La guerra colonial portuguesa en la poesía testimonial de Fernando Assis Pacheco y Manuel Alegre: diálogos, congruencias y incongruências}

\section{Resumen}

Este artículo analiza la poesía testimonial de Fernando Assis Pacheco y Manuel Alegre, ambos excombatientes de la guerra colonial portuguesa en África. Los análisis se detienen en publicaciones realizadas cerca el enfrentamento o en su apogeo, a saber: Cuidar dos vivos (1963) y Catalabanza, Quilolo e Volta (1976), de Fernando Assis Pacheco, y Praça da Canção (1965) y Canto e as armas. (1967), de Manuel Alegre. Partiendo de las concepciones de Walter Benjamin (2012) de crisis del compromiso tácito entre el lector y el narrador moderno y del paroxismo de la imposibilidad de representación artística de una catástrofe humana como la guerra, tratamos de mostrar cómo cada uno de los autores portugueses elaboraba estéticamente su testimonio para retratar en verso la brutalidad cotidiana del front y los traumas que allí se traen. Atentos a los diálogos, las congruencias y las incongruencias entre las producciones de los poetas, esperamos cuestionar que las guerras son, paradójicamente, experiencias colectivas momentáneas, pero vividas individualmente.

Palabras-clave: Fernando Assis Pacheco. Manuel Alegre. Guerra colonial portuguesa. Testimonio. Memoria.

Recebido em: 28/09/2020 // Aceito em: 01/12/2020 
A experiência das duas grandes guerras e das dezenas de conflitos de menores proporções que as sucederam, descortinaram o horror que a humanidade é capaz de produzir. A desumanização dos soldados nas trincheiras, a tecnologia - antes esperança de avanços no bem-estar humano, agora colocada a serviço da morte em escala industrial -, a banalidade do mal e a elaboração dos traumas físicos e psicológicos dos sobreviventes etc. são algumas das complexas questões inventariadas no mórbido espólio de catástrofes do século XX.

No sumário desses tristes capítulos da história da humanidade, está a Guerra Colonial portuguesa. Para Isilda Braga da Costa Monteiro (2016, p. 703), a guerra travada entre Portugal e suas antigas colônias africanas entre 1961 e 1974 é ainda, mais de trinta anos após seu fim, incômoda e de difícil abordagem. Para as gerações que não viveram diretamente o trauma dessa guerra. O conflito travado em África "corresponde já a um passado distante, quiçá pouco interessante" (MONTEIRO, 2016, p. 703). Além disso, de acordo com Renè Pelissier, estudioso da questão colonial portuguesa, "as guerras da descolonização deixam geralmente uma lembrança amarga no espírito dos europeus que as travam" (PELISSIER, 2003, p. 157). Os portugueses, obviamente, não são exceção.

Nesse sentido, coube à arte, em especial à literatura, arcar com as novas configurações do tempo e não permitir que os horrores vivenciados nas guerras caíssem no esquecimento. Historicamente, a literatura relaciona-se dialeticamente com a realidade, iluminando aspectos do processo social que, de outra forma, poderiam permanecer obscurecidos. É pungente o poder que essa manifestação artística tem de representar a realidade e, com isso, fomentar questionamentos importantes a respeito das 
condições concretas em que transcorre a experiência histórica humana. Porém, após as catástrofes do século XX, uma questão fundamental se interpôs: como a literatura seria capaz de dar trato estético à experiência traumática da guerra? Em outras palavras: seria possível reelaborar artisticamente os horrores indescritíveis vivenciados pelos poucos que conseguiram regressar com vida dos fronts, ou somente o silêncio daria conta de expressar o indizível? A esse respeito, Walter Benjamin, ainda sob o impacto da primeira Guerra Mundial, identifica a perda progressiva de "uma faculdade que nos parecia totalmente segura e inalienável: a faculdade de intercambiar experiências" (BENJAMIN, 2012, p. 213). Ou seja, a humanidade está perdendo a arte de narrar.

O filósofo alemão - que, anos mais tarde, em um gesto desesperado, encontrará no suicídio a "solução final" para pôr fim às perseguições antissemitas do regime nazista - chega ao seguinte diagnóstico: a arte de narrar está progressivamente tornando-se rara, porque ela parte, fundamentalmente, da transmissão de uma experiência, cujas condições de realização já não existem mais na sociedade. Nas palavras de Benjamin,

Basta olharmos um jornal para nos convencermos de que seu nível está mais baixo do que nunca, e que da noite para o dia não somente a imagem do mundo exterior, mas também a do mundo moral sofreu transformações que antes teríamos julgado como absolutamente impossíveis. Com a guerra mundial começou a tornarse manifesto um processo que desde então segue ininterrupto. Não se notou, ao final da guerra, que os combatentes voltavam mudos do campo de batalha; não mais ricos, e sim mais pobres em experiência comunicável? (BENJAMIN, 2012, p. 214).

Benjamin lembra ainda a diferença entre a enxurrada de livros sobre a guerra e a experiência transmitida de boca em 
boca, evidenciando que as obras que abarrotavam as vitrines das livrarias não davam conta de experiências tão radicais quanto os massacres dos campos de batalha. E não havia nada de anormal nisso, continua o filósofo, porque nunca antes a humanidade se vira às voltas com uma brutalidade de tal proporção, capaz até de tornar inviável a faculdade de intercambiar experiências pela da narrativa.

\begin{abstract}
Uma geração que ainda fora à escola num bonde puxado por cavalos encontrou-se desabrigada, numa paisagem em que nada permanecera inalterado, exceto as nuvens, e, debaixo delas, num campo de forças de torrentes e explosões destruidoras, o frágil e minúsculo corpo humano. (BENJAMIN, 2012, p. 214).
\end{abstract}

Desenhava-se, então, a crise do narrador moderno, cindido entre a necessidade do testemunho - seja com o objetivo de advertência, para que não se repitam os horrores do passado, ou como registro individual e coletivo daqueles que sobreviveram - e a falta de parâmetros estéticos capazes de reelaborar, em forma literária, o trauma das memórias. A esse respeito, Mário César Lugarinho (2011, p. 266) observa que, hoje, na era dos extremos - para usarmos um termo bastante conhecido, elaborado pelo historiador marxista Eric Hobsbawm (1995) - instalou-se, na literatura, uma crise jamais vista desde a ascensão do romance moderno. ${ }^{1}$ Sem dúvida, a brutalidade das guerras do século XX, conforme demonstrou Walter Benjamin (2012), foi fator decisivo para essa tensão. Após tal nível de catástrofe humana, o compromisso tácito entre as instâncias do narrador e do leitor se estabeleceu através de contornos mais complexos por envolverem questões humanas delicadas, como o

1 Sobre a relação histórica entre o narrador e a origem do romance moderno, é esclarecedora a seção de número cinco do já citado ensaio "O narrador", de Walter Benjamin (2012). 
luto, a humilhação, a dor física e psicológica etc. Ao se debruçar sobre o penoso ato de transmissão da experiência extrema, via elaboração estética literária, o narrador moderno afirma o compromisso de testemunhar a realidade vivenciada, enquanto o leitor, por sua vez, é convidado a abandonar a confortável e secular posição de receptor passivo, para tomar lugar no processo ativo de "exorcismo" da memória traumática.

No entanto, conforme evidencia o escritor italiano Primo Levi - que viveu, entre 1944 e 1945, em um campo de concentração nazista -, o resgate da memória é tão doloroso e tão inacreditável que o silêncio e o esquecimento são opções mais que compreensíveis, são desejáveis. Em sua obra mais conhecida, É isto um homem?, Levi pergunta, numa frase muito significativa, se vale a pena todo o esforço de rememoração, dizendo: "bem sei que, contando isso, dificilmente seremos compreendidos, e talvez seja bom assim" (LEVI, 1988, p. 25). A questão que se coloca, porém, é que o esquecimento também é uma tarefa difícil. Para Geraldo Antônio Soares, não ser compreendido, nos termos propostos por Primo Levi, "pode ser bom, porque implica envolver muito o leitor com esta miséria humana, algo que quem sofre de múltiplas formas, no vivido, na memória e na narrativa, não deseja." (SOARES, 2012, p. 917).

Apesar da dificuldade em encontrar parâmetros para situar a catástrofe vivida, e no risco da incompreensibilidade por parte do leitor, Márcio Seligmann-Silva realça que 'a 'passagem' do 'literal' para o 'figurativo' é terapêutica" (SELIGMANNSILVA, 2003, p. 89, grifos do autor). Em outras palavras, o ato de testemunhar uma situação limítrofe pode auxiliar o sobrevivente a elaborar o trauma do passado e seguir adiante. SeligmannSilva continua o raciocínio: 
Por um lado, tanto o testemunho deve ser visto como uma forma de esquecimento, uma 'fuga para frente', em direção à palavra e um mergulhar na linguagem, como também, por outro lado, busca-se igualmente, através do testemunho, a libertação da cena traumática. (SELIGMANN-SILVA, 2003, p. 89, grifos do autor).

A busca da "libertação da cena traumática" como uma "fuga para frente", através do trato estético literário, é uma constante em diversos casos de catástrofes humanas, como: o já citado Primo Levi e a Shoah, em vários títulos, especialmente É isto um homem?, de 1947; Rigoberta Menchú e o genocídio do povo originário guatemalteco, em Me chamo Rigoberta Menchú e assim me nasceu a consciência, de 1982; Carolina Maria de Jesus e o cotidiano das favelas brasileiras, em Quarto de despejo, de 1960; dentre tantos outros. ${ }^{2}$ Nesse sentido de vivência traumática, durante as décadas de 1960 e 1970, Fernando Assis Pacheco e Manuel Alegre, então jovens universitários portugueses de classe média, testemunharam, em forma de poesia, um dos mais tristes capítulos da história de seu país - as guerras coloniais em África.

Entre 4 de fevereiro de 1961 e 25 de abril de 1974, Portugal contrapôs-se a suas antigas colônias no continente africano. Países como Angola, Moçambique e Guiné-Bissau foram sujeitados a uma guerra ultramarina inconsequente - como todas, no fundo, o são -, fruto de uma política externa anacrônica e de inspiração imperial colocada em prática pelo então regime ditatorial de António de Oliveira Salazar - o Estado Novo. O conflito que mobilizou perto de um milhão de soldados, a maioria deles jovens em idade universitária, reavivou feridas ainda não cicatrizadas da segunda Guerra Mundial, que, décadas antes, varrera todo o

2 Shoah é a palavra hebraica que significa destruição, ruína, catástrofe. É o termo utilizado para denominar a destruição sistemática do povo judeu da Alemanha e da Europa durante o regime nazista entre 1933 e 1945. 
continente europeu. Para um país de pequena extensão territorial e populacional como Portugal, a excursão militar em África resultou em uma desastrosa tragédia que poderia ser comparada - se isso fosse possível - com as experiências estadunidenses nos conflitos da Coréia (1950 - 1953) e do Vietnã (1955 - 1975), já no contexto da Guerra Fria.

É nesse turbulento momento histórico que dois estudantes da Universidade de Coimbra, na década de 1950, Fernando Assis Pacheco (1837 - 1995) e Manuel Alegre (1936 -), são convocados a servir nos campos de batalha de Angola, ainda nos primeiros anos do conflito. Do que lá viveram e com o que de lá foram obrigados a conviver após voltarem vivos, os ex-soldados testemunharam, em poesia, os horrores dos assassinatos, as doenças da savana africana, as longas noites de espera nas trincheiras, a morte à espreita pelo cano do fuzil inimigo ou pelas minas terrestres plantadas nos caminhos, sem contar os pesadelos, os traumas e as crises de pânico pós-regresso. Nesse sentido, para Margarida Calafate Ribeiro (2001), as produções artísticas que abordam a guerra colonial portuguesa - das quais Assis Pacheco e Manuel Alegre são exemplares de grande expressão -, associaram outro elemento ao paradigma já bastante complexo da literatura testemunhal. Segundo a autora, é possível observar claramente na produção desses dois autores:

[a] melancolia, no sentido freudiano do termo, ou seja, como expressão de um sentimento de luto por uma perda individual - o paraíso perdido anterior à guerra pela desagregação do sujeito - e coletivo - a configuração ultramarina da nação e, consequentemente, a sua dimensão imperial. (RIBEIRO, 2001, p. 73).

O conjunto de traumas, observado por Calafate Ribeiro (2001), é a pedra de toque do testemunho de nossos dois poetas. 
Porém, apesar de ambos tratarem do tema dos fronts, há clara divergência quanto ao tratamento estético que eles dispensam a essas vivências. Veremos, por exemplo, que, em Manuel Alegre, a guerra colonial aparece como uma fratura que atravessa, em maior ou menor grau, toda a sua produção artística - por vezes, de modo sutil e metafórico -, enquanto, em Assis Pacheco, o relato dos dias em África se apresenta de maneira condensada em suas pouquíssimas produções, assumindo um tom visceral e impactante.

Vejamos, de início, "Nambuangongo, meu amor", do livro Praça da Canção, publicado em 1965, por Manuel Alegre. Nos versos, o autor utiliza o recurso estilístico do contraste para tentar dar conta da catástrofe vivida na cidade angolana cujo nome dá título ao poema.

\section{NAMBUANGONGO, MEU AMOR}

Em Nambuangongo tu não viste nada não viste nada nesse dia longo longo a cabeça cortada e a flor bombardeada não tu não viste nada em Nambuangongo

Falavas de Hiroxima tu que nunca viste em cada homem um morto que não morre.

Sim nós sabemos Hiroxima é triste mas ouve em Nambuangongo existe em cada homem um rio que não corre.

Em Nambuangongo o tempo cabe num minuto em Nambuangongo a gente lembra e a gente esquece em Nambuangongo olhei a morte e fiquei nu. Tu não sabes mas eu digo-te: dói muito.

Em Nambuangongo há gente que apodrece.

Em Nambuangongo a gente pensa que não volta cada carta é um adeus em cada carta se morre cada carta é um silêncio e uma revolta. Em Lisboa na mesma isto é a vida corre. 
E em Nambuangongo a gente pensa que não volta.

É justo que me fales de Hiroxima.

Porém tu nada sabes deste tempo longo longo tempo exactamente em cima do nosso tempo. Ai tempo onde a palavra vida rima com a palavra morte em Nambuangongo.

(ALEGRE, 2009, p. 80).

Logo no título do poema, percebemos o intertexto com o filme Hiroshima, meu amor, de 1959, do diretor francês Alain Resnais. ${ }^{3} \mathrm{O}$ desenrolar da trama conta a história de amor de um jovem casal em meio ao que restou da cidade japonesa após o criminoso ataque nuclear estadunidense durante a Segunda Guerra. Emmanuelle Riva interpreta uma atriz francesa sem nome - identificada apenas por "Ela" - que, ao ser contratada para atuar, no Japão, em um filme sobre a paz pós-guerra, conhece e se apaixona pelo personagem de Eiji Okada - igualmente sem nome e identificado por "Ele". Além da impossibilidade amorosa - ambos os personagens são casados com outras pessoas -, o filme aborda as feridas não cicatrizadas de uma nação que sentiu, na própria pele, uma das maiores catástrofes da humanidade. "Ela" carrega consigo a culpa de outro amor proibido - havia se apaixonado, anos antes, por um soldado nazista -, já "Ele" é atormentado pelo trauma do ataque de 1945 . O casal, então, será obrigado a enfrentar fantasmas individuais e coletivos em prol de uma paixão.

Diferentemente do filme de Resnais, porém, o poema de Manuel Alegre não dá espaço para qualquer tipo de sentimento terno. "Nambuangongo, meu amor" detalha a tediosa e mórbida dificuldade dos soldados em lidarem com o "dia longo longo"

3 O diretor é conhecido também pelo curta Noite e neblina, de 1956, em que são tratados os horrores dos campos de concentração nazistas, em especial do mais conhecido e temido deles: Auschwitz. 
(ALEGRE, 2008, p. 80), que parece nunca chegar ao fim - a repetição do adjetivo, nesse caso, com valor superlativo, reforça o sentimento de marasmo. Observamos também cenas de brutalidade - como a cabeça cortada e a flor bombardeada - em paralelo com a angústia causada pela normalidade que se passa longe dali, "Em Lisboa na mesma isto é a vida corre". (ALEGRE, 2008, p. 80). ${ }^{4}$ Nesse sentido, o testemunho do real da guerra contrasta com a ilusão de normalidade vivida pelos outros que tiveram a sorte de ficar em Portugal. A comparação de posições distintas - o soldado que sofre e o cidadão português que ignora esse sofrimento - é um recurso utilizado com o intuito de aproximar o leitor da perplexidade testemunhada. Embora não se trate de medir tragédias, a aproximação da violência entre as cidades de Nambuangongo e de Hiroshima é outro recurso de contraste que carrega ainda mais as tintas que compõem o quadro da rotina dos combatentes. Assim como a bomba atômica lançada sobre a cidade japonesa pôs em evidência o potencial de desumanização da guerra, o poema de Manuel Alegre nos mostra que, diante da morte, o homem está sempre despido de qualquer humanidade, "em Nambuangongo, olhei a morte e fiquei nu". (ALEGRE, 2008, p. 80).

Diante da incredulidade da capacidade de destruição humana, a iminência da morte é outra constante no poema, como nos versos: "cada carta é um adeus em cada carta se morre / cada carta é um silêncio e uma revolta". (ALEGRE, 2008, p. 80). Novamente, o recurso do contraste vem à baila, dessa vez para realçar a necessidade de se testemunhar os horrores em Angola, na figura da carta endereçada àqueles que ficaram em

\footnotetext{
4 A imagem da cabeça cortada é tema também do poema "A bola", de Jonas Negalha. Em Portugal, os versos ficaram famosos na voz e na melodia de Luís Fernando Cília. "[...] Soldados/ Jogam/ Futebol/ Com a bola/ Que pula/ Sangrando/ No chão/ De Angola. Ninguém/ Distingue/ Na bola/ Ensopada/ [...] A cabeça/ De um negro/ Sangrando/ Que rola/ No chão/ De Angola.” (NEGALHA, 2011, p. 435-436).
} 
Lisboa, ao mesmo tempo em que demonstra a impossibilidade de se cumprir o relato - restam somente o silêncio e a revolta. Em "Nambuangongo, meu amor", os contrastes se aproximam, se confundem e integram uma só dinâmica, pois, na guerra, é "Aí o tempo onde a palavra vida rima/ com a palavra morte em Nambuangongo" (ALEGRE, 2008, p. 80).

Assim como em Manuel Alegre (2008), encontramos, na poesia de Fernando Assis Pacheco, o paroxismo causado pela incredulidade da violência cotidiana nos campos de batalha e a impossibilidade de testemunhar o vivenciado. É o que se pode verificar em Cuidar dos Vivos, de 1963, primeiro livro de Assis Pacheco. Essa produção, além da inegável qualidade estética, tornou-se importante por conter aqueles que são considerados os primeiros poemas de denúncia e testemunho da frustrada campanha portuguesa em África. O título da obra faz referência ao lema do terremoto de Lisboa - outra grande catástrofe que marcou o país - atribuído ao Marquês de Alorna sobre a necessidade de "enterrar os mortos e cuidar dos vivos". ${ }^{5}$ Ou seja, logo de entrada o poeta dialoga com o passado português e implicitamente imbui ao leitor certa responsabilidade de assumir no legado do passado sua elaboração enquanto presente. Já o título da seção, "Versos que o autor mandou de Nambuangongo ao editor", remete ao fato de que essa parte da obra foi editada e financiada pelo pai do poeta, enquanto Assis Pacheco lutava pela vida e pela pátria nos campos de batalha. Margarida Calafate Ribeiro (2001, p. 77) lembra que, em vários momentos da produção do poeta, a figura paterna atua ora como uma espécie de confessor, único capaz de compreender o horror experienciado, ora como imagem da

\footnotetext{
5 O terremoto de Lisboa ou sismo de Lisboa ocorreu no primeiro dia do mês de novembro de 1775 , resultando na destruição quase integral da capital portuguesa, especialmente na zona da Baixa, e atingindo cidades litorâneas como Algarve e Setúbal. Estima-se que mais de 10 mil pessoas perderam a vida durante o fenômeno. O desastre ainda hoje é lembrando em monumentos, pinturas e poemas.
} 
própria pátria Portugal, culpada por abandonar seus filhos para morrer longe de casa.

Ainda nessa seção de poemas endereçados à figura paterna, encontramos os versos de "Há um veneno em mim..." (PACHECO, 2006, p. 45). De modo parecido com "Nambuangongo, meu amor" (ALEGRE, 2008, p. 80), o leitor encontra o testemunho de tédio mórbido, como nos versos: "há um silêncio aflito quando os ombros/ se cobrem de suor pesado e frio." (PACHECO, 2006, p. 45), evidenciando que a morte está sempre à espreita e pode surgir a qualquer momento nos tiros juntos à noite. Vejamos o poema na íntegra.

\section{HÁ UM VENENO EM MIM...}

Há um veneno em mim que me envenena, um rio que não corre, um arrepio, há um silêncio aflito quando os ombros se cobrem de suor pesado e frio.

Há um pavor colado na garganta, e tiros junto à noite, e o desafio (algures na escuridão) de alguma coisa calando o fraco apelo que eu envio.

Há um papa que morre enquanto escrevo estas linhas de angústia e solidão há o fogo da Breda, os olhos gastos.

Há a mulher que espera confiada um pálido vazio aerograma; e há meu coração posto de rastos.

(PACHECO, 2006, p. 45)

Os sintomas de envenenamento que o poema descreve são resultados da peçonha da guerra. Tomados em conjunto, sensações como arrepio, pavor, suor pesado e frio podem ser lidos como o prognóstico da comorbidade maior que é a desumanização implícita na situação de conflito armado. Já o verso dedicado ao 
papa, que morre enquanto o poeta escreve, é uma alusão à morte do Sumo Pontífice da Igreja Católica, o Papa João XXIII, figura por quem, segundo Margarida Calafate Ribeiro (2001, p. 75), o poeta nutria grande estima. Novamente em congruência com o poema de Manuel Alegre (2008, p. 80), notamos a necessidade de vincular-se com o cotidiano que transcorre na poesia. Os dias longos do front, o sentimento de abandono da orfandade e os sintomas da guerra fazem das linhas de angústia e solidão, de Fernando Assis Pacheco (2006, p. 45), um retrato traumático da expedição colonial.

Diferentemente de Cuidar dos Vivos (1963), escrito em partes sob a mira do fuzil inimigo e enviado ao pai como testemunho in loco, o livro Câu Kiên: Um Resumo é publicado em 1972, quando Fernando Assis Pacheco havia regressado a Portugal - o conflito se estenderia ainda por mais três anos. Para fugir à censura imposta pela ditadura do regime Salazarista-que, apesar de enfraquecido perante a opinião pública e humilhado pelo fracasso das expedições ultramar, ainda desfrutava de um largo aparelho estatal de repreensão política -, Assis Pacheco busca nomes e referências em outro conflito armado para denunciar o que viu e viveu; trata-se da campanha estadunidense no Vietnã. Em 1976, o título, que fazia referência a uma cidade vietnamita, é alterado para Catalabanza, Quilolo e Volta, por sua vez, cidades angolanas onde o poeta serviu. Apesar do contexto de elaboração literária distinto, Margarida Calafate Ribeiro percebe que essa obra, assim como a de 1963, pode ser lida "como uma longa conversa-testemunho entre o poeta e o seu pai-pátria, sobre o que era aquela guerra, a sua falta de virtude e heroísmo e o estado que deixava os homens." (RIBEIRO, 2001, p. 78). 
O monólogo com a figura paterna está presente logo no primeiro poema do livro, "E Havia Outono?" (PACHECO, 2006, p. 49). O poema chama atenção, também, tanto do ponto de vista estrutural como temático, pelo tom dialógico sobre o qual se constrói uma tentativa de resposta à pergunta que seu título encerra - havia outono em África? -, a qual pode ser lida como dúvida levantada por seu principal correspondente durante a guerra, a figura do pai-pátria.

\section{E HAVIA OUTONO?}

Havia o que não esperas: árvores, altas árvores de coração amargo, e o vento rodopia e leva as folhas cegas sobre a cabeça do homem. Havia um coto de sangue. [...]

Havia o que não esperas: horas, minutos como horas para mastigar o sustocado pelas trevas da mata.

$\mathrm{E}$ as minas os fornilhos as armadilhas com trotil ah não vou contar-te um décimo desta libertinagem.

[...]

Havia o que não esperas: risos, lágrimas como risos, lágrimas como folhas cegas explodindo ao de leve; e a morte -

(PACHECO, 2006, p. 49).

O tom dialógico presente no poema, segundo Margarida Calafate Ribeiro (2000, p. 3), faz contato com outro gênero textual, a crônica. Para a autora, os versos de Pacheco ora fixam 
o cotidiano dos soldados em Angola, ora informam e trazem notícias, ora são irônicos, parodiando o discurso oficial. A pergunta no título é o pino da granada responsável pela explosão de memórias dos acontecimentos em África. O primeiro verso já assinala que o poema é produto de imagens que vão "explodindo" ao sabor da memória do poeta, fato que confere ao testemunho um ritmo frenético que vai ao encontro do ritmo da própria guerra - "Havia um coto de sangue", "Minutos como horas", "as minas", "armadilhas", "risos", "lágrimas como risos", "lágrimas" e "a morte" são alguns exemplos. Ao mesmo tempo em que o poeta revive os dias de combate, o poema oferece ritmadamente ao leitor a possibilidade de elaborar o impossível da atmosfera sombria da guerra. Trata-se de ousar desafiar a crise imposta ao narrador moderno e a impossibilidade de transmissão da experiência sobre a qual vimos Walter Benjamin argumentar (2012, p. 214) - é o que se percebe nos versos: "ah não vou contar-te um décimo/ desta libertinagem." (PACHECO, 2006, p. 49). Nesse sentido, o testemunho de "E Havia Outono?", na perspectiva de Margarida Calafate Ribeiro, implica:

[u]ma promessa de verdade garantida pela dimensão performativa inerente ao testemunho, se faça luz sobre um fato a partir do qual se estabelece um cúmplice compromisso entre quem conta - que assim cumpre a sua função de testemunha - e quem ouve - que assim toma conhecimento da verdade e não mais pode dizer que não sabia, gerando-se o pacto de responsabilidade partilhada sobre o narrado inerente à funcionalidade da literatura-testemunho. (RIBEIRO, 2000, p. 3).

Uma vez mais, como na poesia de Manuel Alegre, o leitor é convidado a assumir papel importante no processo de reelaboração da memória traumática. Porém, Mário César Lugarinho nota que, diferentemente de seu compatriota, "a 
poesia de Assis Pacheco faz da guerra o tema mais permanente e recorrente, tratará do trauma e não da sua superação e, por isso, mais fixado em Nambuangongo do que Alegre." (LUGARINHO, 2011, p. 265). Como o próprio Francisco Assis Pacheco nos informa nos versos de "Monólogo e Explicação" - "Dizem que a guerra passa: esta minha/ passou-me para os ossos e não sai" (PACHECO, 2006, p. 51) -, os dias e as noites em África são fraturas insuperáveis, condensadas e sentidas nos próprios ossos do poeta.

O testemunho da brutalidade da guerra colonial na poética de Fernando Assis Pacheco atinge síntese máxima em "O Garrote", também de Catalabanza, Quilolo e Volta, de 1976. Nessa ocasião, o poeta discute o complicado paradoxo entre o ato de elaboração poética e a situação de extrema violência que o cercava de todos os lados nos campos de batalha e que, mesmo após o regresso, continua bastante vivo na memória.

\section{O GARROTE}

Ribeiras limpas acudi-me.

Vou ficar vivo encostado

a esta memória de trampa.

Os meus olhos já foram brilhantes.

Sei fazer alguns versos mas nem sempre

Eu narrador me confesso

A guerra lixou tudo.

É curioso como se bebia

água podre.

Não falando no vinho, muito.

Durante os ataques doiá-me um joelho.

Estou pronto, pensei.

Ninguém me conhece.

Os ratos são felizes.

[...]

Deixei-me disso.

Sou feiíssimo ao espelho.

Recordação súbita duma litografia 
castelhana: o garrote.

Não vos perdoo.

$[\ldots]$

E depois há um pisa uma armadilha.

Houve um que pisou uma armadilha!

Sei fazer versos. Ou seja: nada.

$\mathrm{O}$ coto em sangue.

Neste ponto o narrador sofreia a imaginação.

Ninguém disse que me conhecia.

Conheço um rato, está em cima duma viga.

Serve para a gente olhar.

(PACHECO, 2006, p. 63)

"O Garrote", de Assis Pacheco (2006), dialoga com a litografia, de mesmo nome, do pintor castelhano Francisco de Goya, produzido entre os anos de 1778 e 1780. No desenho, há a representação de um homem maltrapilho com as mãos atadas e preso pelo pescoço, a um tronco de madeira, por uma espécie de colar de aço, chamado de garrote. Salta aos olhos do observador a expressão de desespero e desconforto do anônimo. Esse sentimento de cruel impotência é o que aproxima o poema do autor português da litografia de Goya. Versos como: "Eu narrador me confesso/ A guerra lixou tudo" e "Sei fazer versos. Ou seja: nada" (PACHECO, 2006, p. 63) marcam o tom exasperador do testemunho. Há a presença da dor física - "doíame um joelho", "o coto em sangue" - e também psicológica, expressa na aproximação humana com imagens que remetem à podridão - "Conheço um rato, está em cima duma viga/ Serve para a gente olhar." (PACHECO, 2006, p. 63-64). A fratura do indizível é, portanto, uma vez mais colocada em discussão: como é possível esquecer um lugar em que até os ratos são felizes e o soldado-poeta não?

O testemunho das minúcias do cotidiano de guerra é um recurso presente tanto em Fernando Assis Pacheco quanto em 
Manuel Alegre. Pormenorizar sensações individuais da guerra, a exemplo da aflição de um garrote ao pescoço, são formas de compor um quadro coletivo de desumanização vivido não só pelos dois ex-combatentes em questão, mas também por aqueles que nunca regressaram das trincheiras. A esse respeito, o exsoldado estadunidense Tim O’Brien escreveu suas memórias sobre o Vietnã:

Você pode contar uma verdadeira história de guerra se continuar contando sobre. E no final, é claro, uma verdadeira história de guerra nunca é sobre a guerra. É sobre a maneira especial que o amanhecer se espalha sobre um rio quando você deve atravessá-lo e marchar para as montanhas para fazer algo que tem medo de fazer. É sobre amor e memória. É sobre tristeza. É sobre irmãs que nunca escrevem de volta e pessoas que nunca ouvem. (O’BRIEN, 2009, p. 83, tradução nossa). ${ }^{6}$

Logo, no testemunho de Tim O'Brien, falar sobre as catástrofes da guerra vai muito além do que apenas narrar a própria guerra - tem a ver igualmente com minúcias do cotidiano, sentimentos contraditórios e até mesmo com pessoas que não estiveram nos fronts de batalha, mas que também sofreram com a espera de alguém que nunca retornou.

Nessa miscelânea de traumas individuais e coletivos, Manuel Alegre vai à história do estado português para retratar o sofrimento de toda uma nação fraturada pela guerra. Na obra O Canto e as Armas, de 1976, o poeta narra, em tom épico, a histórica e desastrosa batalha de Alcácer-Quibir, que deu origem ao mito do sebastianismo em Portugal. ${ }^{7}$ Por analogias, metáforas

\footnotetext{
$6 \quad$ "You can tell a true war story if you just keep on telling it. And in the end, of course, a true war story is never about war. It's about the special way that dawn spreads out on a river when you must cross that river and march into the mountains and do thing you are afraid to do. It's about love and memory. It's about sorrow. It's about sisters who never write back and people who never listen." (O’BRIEN, 2009, p. 83).

7 Alcácer-Quibir é a cidade marroquina onde, em 1578, o exército português, liderado pessoalmente pelo rei Dom Sebastião I, mediu forças contra as tropas saadianas do sultão Mulei Moluco. A batalha resultou na derrota de Portugal, no aprisionamento
} 
e contrastes, Manuel Alegre compõe versos que aproximam as duas derrotas portuguesas em África. Poemas como "Explicação de Alcácer-Quibir" (ALEGRE, 2009, p. 130) refletem o passado e o presente da nação por meio de uma sobreposição histórica que vê no expansionismo colonial português situações diferentes para uma mesma catástrofe.

\section{EXPLICAÇÃO DE ALCÁCER-QUIBIR}

Quantos desastres dentro de um desastre.

Alcácer-Quibir foi sempre

o passado por dentro do presente

ó meu país que nunca te encontraste.

Senhor no mar e em terra dependente conquistado de cada vez que conquistaste Alcácer-Quibir foi sempre o ires perder-te em cada índia que ganhaste. $[\ldots]$

Alcácer-Quibir é estar aqui a ver o morrer o Sol em cada tarde.

E este riso que chora. E esta sombra que ri.

Este fantasma sobre a nossa idade.

E esta paz como guerra. Este plantar o pão que os outros comem.

Este Alentejo de desilusão em cada homem

Estes barcos que partem com homens e armas não já para colher além do mar a terra mas para levar além do mar a guerra.

E naufragar de novo. E de novo perder além do mar o que se deixa em terra. (Porque o mais é espuma.)

Alcácer-Quibir é ir morrer

além do mar por coisa nenhuma 
$[\ldots]$

Alcácer-Quibir és tu Lisboa.

E há uma rosa de sangue no branco areal.

Há um tempo parado no tempo que voa.

Porque um fantasma é rei de Portugal.

(ALEGRE, 2009, p. 130)

O poema de Alegre mantém franco diálogo com o imaginário português de grandeza. Durante o que ficou conhecido como a "era dos descobrimentos" ou das "grandes navegações" - entre o século XV e o início do século XVII -, Portugal assumiu lugar de destaque na exploração intensiva do globo terrestre em busca de novas rotas de comércio e matéria-prima. Como resultado das descobertas, a pequena nação da península ibérica desfrutou de riqueza e prestígio que, posteriormente - com a acirrada competição de países como Inglaterra, Espanha e Holanda -, não se sustentaram. Porém, os anos vividos como potência militar e econômica incutiram no imaginário popular português um forte ideário de nacionalismo e grandeza. De volta ao século XX, o regime de António de Oliveira Salazar empenhou-se na recuperação e no reforço desse sentimento com o objetivo de legitimar uma nova campanha no continente africano. ${ }^{8}$

Em "Explicação de Alcácer-Quibir" (ALEGRE, 2009, p. 130), o ideário de grandeza português fica explícito quanto ao tom épico digno dos versos de Os Lusíadas (1572). Como sabemos, a epopeia de Luís Vaz de Camões narra a descoberta do caminho marítimo para a Índia pelo navegador Vasco da Gama e sua tripulação, enquanto se vão descrevendo outros episódios da fundação de Portugal. Porém, no poema de Manuel Alegre, o ideário épico é despido de qualquer atributo histórico positivo, de modo que, ao fim e ao cabo, é o retrato brutal da guerra em

8 Foi comum às ditaduras européias do século XX a tentativa de resgate do sentimento popular de grandeza. Os casos do terceiro Reich alemão e dos "fascis" italianos são exemplares. 
África que aparece em primeiro plano. É o que percebemos nos versos: “Quantos desastres dentro de um desastre/ Alcácer-Quibir foi sempre/ o passado por dentro do presente" (ALEGRE, 2009, p. 130). A imagem do passado que acontece concomitantemente ao presente é um alerta e uma crítica ao anacronismo da guerra colonial.

Trazer à tona a derrota histórica de Alcácer-Quibir põe contra a parede uma nação que, aparentemente, não aprendeu com os erros do passado: "Estes barcos que partem com homens e armas/ não já para colher além do mar a terra/ mas/ para levar além do mar a guerra." (ALEGRE, 2009, p. 130). Trata-se de uma catástrofe anunciada que impõe aos jovens soldados, dos quais o próprio poeta fez parte, uma nova derrota, um novo naufrágio: "E naufragar de novo. E de novo perder/ além do mar o que se deixa em terra" (ALEGRE, 2009, p. 130). Por fim, o poema coloca, em mesmo plano, o rei Dom Sebastião, responsável pela carnificina de 1578, e António Salazar, representado pela mórbida imagem de um fantasma. Diz o poeta: “Alcácer-Quibir és tu Lisboa/ E há uma rosa de sangue no branco areal./ Há um tempo parado no tempo que voa./ Porque um fantasma é rei de Portugal.” (ALEGRE, 2009, p. 130).

As catástrofes do passado e do presente percorrem todo O Canto e as Armas (1967). Poemas como "Abaixo El-Rei Sebastião", "A batalha de Alcácer-Quibir" e "Perigrinação" marcam a busca por paralelos históricos. Para Mário César Lugarinho (2011, p. 263), quando lidos em conjunto, os paralelos retratam as continuidades do projeto político e econômico do imperialismo português sob a justificativa de uma pretensa missão civilizadora que teima em manter o passado por dentro do presente. 
Em 1963, após liderar um frustrado motim militar em Angola, Manuel Alegre regressa a Portugal. No ano seguinte, após o cárcere, o poeta torna-se voz ativa na imprensa, denunciando as péssimas condições das tropas e os horrores vividos no front, o que o leva à perseguição pelo Estado Novo e ao exílio em França e Argélia. Durante o período de desterro, Manuel Alegre intensifica sua produção intelectual e política, chamando a atenção de toda a comunidade europeia para o que se passava nas terras além-mar - data dessa época o já citado $\mathbf{O}$ Canto e as Armas (1967) e Um barco para Ítaca (1971), obra em que o poeta dialoga com outro poema épico, a Odisséia, de Homero. Atualmente, Manuel Alegre mantém-se ativo tanto na vida política - em 2006, concorreu à presidência de Portugal, ocasião em que atingiu números expressivos, somando mais de $20 \%$ dos votos válidos, o que lhe garantiu o segundo lugar no pleito -, quanto na produção literária, em que a guerra colonial é tema recorrente - além de poemas, escreveu os romances Jornada em África, de 1989, e Rafael, de 2003.

Já Fernando Assis Pacheco regressou da guerra em 1965. No mesmo ano, voltou a se dedicar ao que chamava de sua "profissão dominante", o jornalismo. Assim como em sua obra poética, a ironia refinada e o olhar atento para o cotidiano foram suas marcas registradas nos diversos artigos e nas colunas veiculados nos principais jornais portugueses da época. Ao contrário de Manuel Alegre, a produção literária de Fernando Assis Pacheco foi escassa, publicaria ainda obras como Viagens na Minha Guerra (1972) e Variações em Sousa (1978), em que o trauma da guerra volta a aparecer como tema central. Em 1995, enquanto fazia compras em uma livraria de Lisboa, Assis Pacheco, aos 58 anos de idade, falece, vítima de enfarto 
fulminante.

A respeito da morte prematura do companheiro de letras e fuzis, Manuel Alegre publica "A mina”. No poema, Alegre parece retomar os versos finais de "Monólogo e explicação", de Assis Pacheco, em que se lê: "Dizem que a guerra passa: esta minha/ passou-me para os ossos e não sai." (PACHECO, 2006, p. 51). Nesse sentido, os traumas vividos nos fronts de Angola são como bombas adormecidas, uma vez instaladas na alma, o ex-combatente carrega eternamente consigo a iminência da morte.

\author{
A MINA \\ Não sei se alguma vez nós voltaremos \\ da guerra onde deixámos partes d'alma. \\ As minas ainda estão a rebentar \\ Trazemo-las por dentro e ninguém pode \\ desarmá-las. \\ A última foi a de Fernando Assis Pacheco \\ não em Zala ou Balacende nem Quilolo \\ mas numa pacata livraria de Lisboa \\ às onze da manhã \\ essa hora fatídica da emboscada.
}

Não me venham dizer que foi enfarte ou acidente cardiovascular. Eu sei que foi a mina armadilhada no coração.

(ALEGRE, 1995, p. 15).

O gramático brasileiro Evanildo Bechara (2010, p. 68) lembra que, por muito tempo, na língua portuguesa, o substantivo "áfrica" foi empregado com o intuito de se remeter a qualquer tipo de façanha e proeza - o que, de certo modo, revive os feitos dos antigos portugueses nessas terras. Porém, a homenagem de Alegre, embora não utilize a palavra, lembra o preço alto a ser pago pela conquista. Como um relógio quebrado que eterniza 
um único momento, “A mina” (ALEGRE, 1995, p. 15) é uma lembrança de que, diante da catástrofe, mesmo os sobreviventes, de um modo ou de outro, morrem.

\section{Referências}

ALEGRE, Manuel. Poesia: 1960 - 2008. Lisboa: Dom Quixote, 2009.

ALEGRE, Manuel. A mina. Jornal de Letras, Lisboa, ano 95, p. 15, 20 dez. 1995.

BECHARA, Evanildo. Gramática Escolar da Língua Portuguesa. 2. ed. Rio de Janeiro: Nova Fronteira, 2010.

BENJAMIN, Walter. O narrador: Considerações sobre a obra de Nikolai Leskov. In: BENJAMIN, Walter. Obras escolhidas I: Magia e técnica, arte e política. 8. ed. rev. São Paulo: Brasiliense, 2012. v. 1, p. 213-240.

HOBSBAWM, Eric. Era dos extremos: o breve Século XX: 1914-1991. São Paulo: Companhia das Letras, 1995.

LEVI, Primo. É isto um homem?. 3.ed. Rio de Janeiro: Rocco, 1988.

LUGARINHO, Mário César. Uma guerra, todas as guerras: as poéticas do tempo e a guerra da África. In: FERREIRA ALVES, Ida Maria; MAFFEI, Luís (org.). Poetas que interessam mais: leituras da poesia portuguesa pós-Pessoa. Rio de Janeiro: Azouge, 2011. v. 1, p. 259-274.

MONTEIRO, Isilda Braga da Costa. A Guerra Colonial (19611974): Memória e História. Um balanço. Coletânea de textos: Congressos da Comissão Internacional de História Militar. Lisboa, p. 703 - 712, 2016. 
NEGALHA, Jonas. A bola. In: RIBEIRO, Maria Calafate; VECCHI, Roberto (org.). Antologia da memória poética da Guerra Colonial. Porto: Edições Afrontamento, 2011. p. 435436.

O'BRIEN, Tim. The things they carried. 3. ed. New York: Houghton Mifflin, 2009.

PACHECO, Fernando Assis. A musa irregular. Lisboa: Assírio \& Alvim, 2006.

RENÉ, Pelissier. Militares, políticos e outros mágicos. Análise Social, Lisboa, v. 37, p. 157-173, 2003.

RIBEIRO, Maria Calafate. No Plaino abandonado um poeta cercado: a guerra colonial na poesia de Fernando Assis Pacheco. In: Actas do VI do Congresso da Associação Internacional de Lusitanistas, UFRJ/ UFF: Rio de Janeiro, 2000.

RIBEIRO, Maria Calafate. Ainda falta um grito: histórias de guerra, trauma e poesia na obra de Fernando Assis Pacheco. Rivista di Studi Portoghesi e Brasiliani, [s. l.], p. 6585, 2001.

SELIGMANN-SILVA, Márcio. Apresentação da questão: a literatura do trauma. In: SELIGMANN-SILVA, Márcio. (org.) História, memória, literatura: o testemunho na era das catástrofes. Campinas: Editora da Unicamp, 2003, p. 52.

SOARES, Geraldo Antonio. Os tormentos da memória trauma e narrativa nos escritos de Primo Levi. Varia Historia, Belo Horizonte, v. 28, n. 48, p. 911-927, jul/dez. 2012. 